\title{
PUBLIC FINANCIAL MANAGEMENT KOTA MANADO, KOTA BITUNG, DAN KABUPATEN MINAHASA SELATAN
}

\section{Victor P.K Lengkong, Olivia S. Nelwan, Bode Lumanauw}

Universitas Sam Ratulangi

\section{A R T I C LE I N F O}

\section{Keywords :}

Regional Finanacial Management (Public Financial

Management)
Based on the results of Manado's public financial management analysis on local financial management there are several key factors on aspect that have been running optimally, namely: avaibility of regulatory framework, accounting and reporting, debt management and public investment, asset management, and audit and supervision external. While the factor aspec key that already good but need to be optimized again, such as cash management, procurement of goods and services, the implementation of external audits and supervision, planning and budgeting and internal control.

The results of Bitung's analysis of public financial management on regional financial management show that there are several key factors or aspects that have been running optimally, namely: planning and budgeting mechanism has been running well, the procurement of goods and services, accounting and reporting, debt management and public investment, assets and execution but need to be optimized again, susch as the avaibility of regulatory framework area, cash management, procurement of goods and services, and implementation of internal control.

The result of public financial management analysis of South Minahasa Regency regarding the management of regional finance indicate that overall the key factors or aspects have been running well, but need to be improved, such as: aspects of local regulatory framework, planning and budgeting, cash management, procurement, accounting and reporting, internal control, debt and public investment, asset management, and external audit supervision.

Berdasarkan hasil analisis public financial management Kota Manado mengenai pengelolaan keuangan daerah terdapat beberapa faktor atau aspek kunci yang telah berjalan secara optimal, yaitu: tersedianya kerangka peraturan perundangan daerah, akuntansi dan pelaporan, pengelolaan hutang dan

investasi publik, pengelolaan aset, serta pelaksanaan 
audit dan pengawasan eksternal. Sementara untuk faktor aspek kunci yang sudah baik namun perlu dioptimalkan lagi, seperti pengelolaan kas, pengadaan barang dan jasa, pelaksanaan audit dan pengawasan eksternal, perencanaan dan penanggaran, serta pengawasan internal.

Hasil analisis public financial management Kota Bitung mengenai pengelolaan keuangan daerah menunjukkan terdapat beberapa faktor atau aspek kunci yang telah berjalan secara optimal, yaitu: mekanisme perencanaan dan penganggaran telah berjalan dengan baik, aspek pengadaan barang dan jasa, akuntansi dan pelaporan, pengelolaan hutang dan investasi publik, aset, dan pelaksanaan audit dan pengawasan ekternal. Sementara untuk faktor aspek kunci yang sudah baik namun perlu dioptimalkan lagi, seperti tersedianya kerangka peraturan perundangan daerah, pengelolaan kas, pengadaan barang dan jasa, serta pelaksanaan pengawasan intern.

Hasil analisis public financial management Corresponding author :

victor.p.k.lengkong@unsrat.ac.id Kabupaten Minahasa Selatan mengenai pengelolaan keuangan daerah menunjukkan bahwa secara keseluruhan faktor atau aspek kunci telah berjalan dengan baik, namun perlu diperbaiki, seperti: aspek kerangka peraturan perundangan daerah, perencanaan dan penganggaran, pengelolaan kas, pengadaan, akuntansi dan pelaporan, pengawasan intern, hutang dan investasi publik, pengelolaan aset, serta audit dan pengawasan eksternal.

\section{Latar Belakang}

\section{PENDAHULUAN}

Sejak diberlakukannya otonomi daerah, desentralisasi fiscal telah memberikan kewenangan yang lebih besar kepada pemerintahan daerah dalam proses perencanaan dan implementasi pembangunan daerah. Pengalihan kewenangan ini disertai dengan pengalihan sumber keuangan dalam bentuk dana perimbangan dari pemerintah pusat kepada pemerintahan daerah. Kewenangan pemerintahan daerah yang semakin besar ini menuntut tata kelola keuangan mulai dari proses perencanaan dan penganggaran, pelaksanaan, dan pengawasan yang lebih baik untuk meningkatkan pertumbuhan ekonomi dan pelayanan publik daerah.

Kenyataan sejak diberlakukannya otonomi dan desentralisasi terjadi peningkatan signifikan transfer belanja ke daerah, namun dalam pelaksanaannya belum secara optimal dimanfaatkan untuk pembangunan oleh pemeritah daerah masing-masing (Laporan Presentasi Bank Dunia, 2011). Sektor Aparatur Pemerintahan dan Pengawasan masih mendominasi belanja pemerintah daerah melebihi sektor Pendidikan, Kesehatan dan Infrastruktur. Sementara pemerintah kabupaten/kota memiliki tanggungjawab besar untuk penyelenggaraan, pembangunan, dan rehabilitasi sekolah, porsi anggaran pembangunan di sektor pendidikan masih sangat kecil. Pada saat sebagian besar anggaran tingkat kabupaten/kota dialokasikan untuk pendidikan, lebih dari $80 \%$ untuk gaji pegawai. Secara umum sektor kesehatan masih 
memperoleh porsi yang kecil. Porsi belanja pemerintah daerah di sektor pendidikan dan kesehatan yang sudah didesentralisasikan justru meningkat, sementara porsi untuk belanja infrastruktur dan pertanian justru menurun dibanding pada masa awal desentralisasi. Meski transfer Pusat ke Daerah terus meningkat dari segi sumber daya fiskal, Kawasan Indonesia Timur masih sangat jauh tertinggal (Laporan Presentasi Bank Dunia, 2011).

Public Financial Management merupakan salah satu alat analisis yang dikembangkan Bank Dunia untuk memperoleh gambaran yang tepat dan menyeluruh tentang pengelolaan keuangan; dan mengembangkan strategi dan kegiatan untuk memperkuat pengelolaan keuangan, serta meningkatkan kapasitas pengelolaan keuangan daerah. Menjadi hal penting bila terdapat aspek-aspek pengelolaan keuangan yang belum terpenuhi, untuk dilakukan perbaikan dan penguatan, dan untuk itu pula analisis PFM sangat dibutuhkan untuk memotret kapasitas masing-masing kabupaten/kota dalam pengelolaan keuangan.

\section{Tujuan Penelitian}

Tujuan khusus dari pelaksanaan analisa public financial management (PFM), antara lain:

- Mengindentifikasi dimensi-dimensi pengelolaan keuangan yang masih perlu ditingkatkan.

- Penting untuk menyusun perencanaan dan penganggaran multi-tahun secara tepat bedasarkan kerangka perundang-undangan yang berlaku.

- Memberikan bahan untuk pembuatan action plan peningkatan kapasitas pengelolaan keuangan daerah;

- Penting untuk memastikan agar anggaran tersusun secara realistis melaui penyusuan analisa standar belanja.

- Tujan akhir adalah terciptanya pengelolaan keuangan daerah yang bebas dari korupsi (fraud) menuju tata kelola pemerintahan yang baik (good government governance).

\section{TINJAUAN PUSTAKA}

\section{Bentuk Hubungan Kewenangan Antara Pusat dan Daerah.}

Terdapat beberapa jenis bentuk hubungan kewenangan antara pusat dan daerah, yakni: dua bentuk yaitu field administration dan local administration. Selanjutnya local administration dapat dilaksanakan secara integrated dan unintegrated. Bentuk lain, delegation to semi-outonomous and parastatal organizations, adalah suatu pelimpahan kewenangan dalam pembuatan keputusan dan manajerial dalam melaksanakan tugas-tugas khusus kepada suatu organisasi yang tidak langsung berada di bawah pengawasan Pemerintah Pusat. Devolution to local government (devolusi), yaitu penjelmaan dari desentralisasi dalam arti luas, yang berakibat bahwa Pemerintah Pusat harus membentuk unit-unit pemerintahan di luar Pemerintah Pusat, dengan menyerahkan fungsi dan kewenangan untuk dilaksanakan secara sendiri atau disebut dengan desentralisasi teritorial. Terakhir, delegation to non-government institutions, yaitu penyerahan atau transfer fungsi dari pemerintah kepada organisasi/institusi non pemerintah. Dengan sebutan lain sebagai privatisasi, yaitu suatu bentuk pemberian wewenang dari pemerintah kepada badan-badan sukarela, swasta, LSM/NGO's, tetapi juga merupakan penyatuan badanbadan milik pemerintah yang kemudian diswastakan, seperti BUMN dan BUMD dilebur menjadi Perseroan Terbatas (PT).

\section{Praktek Desentralisasi di Indonesia}

Indonesia adalah negara kesatuan, yang dibentuk setelah proklamasi 17 Agustus 1945 dengan berlandaskan kepada pasal 1 Undang-Undang Dasar 1945 yang mengatur mengenai bentuk negara Indonesia. Dalam kaitannya dengan desentralisasi, Undang-Undang Dasar 1945 tidak mengatur secara rinci mengenai penyelenggaraan desentralisasi di Indonesia. Undang-Undang Dasar 1945 menyebutkan 35 
bahwa aturan yang lebih khusus mengenai pemerintah daerah dan kekuasaannya akan ditetapkan dengan undang-undang.

Sejak masa kemerdekaan, ada 6 (enam) undang-undang (UU) dan 1 (satu) Instruksi Presiden (Inpres) tentang aspek politik dan administrasi pemerintah daerah, yakni UU No. 1 tahun 1945, UU No. 22 tahun 1948, UU No. 1 tahun 1957, Instruksi Presiden No. 6 tahun 1959, UU No. 18 tahun 1965, UU No. 5 tahun 1974, UU No. 22 tahun 1999, dan UU No. 32 tahun 2004. Tiap-tiap undang-undang tersebut memberikan pendekatan yang berbeda untuk sistem desentralisasi. Berdasarkan data dari Kementerian Dalam Negeri, pada bulan Mei 2013, di Indonesia terdapat 34 provinsi, 407 kabupaten, dan 99 kota. Setiap tingkatan pemerintahan daerah, diberi tanggung jawab tertentu.

Provinsi di Indonesia memiliki fungsi yang terbatas. Wewenang utama pemerintah provinsi adalah dalam hal yang berkaitan dengan urusan dan layanan multi-jurisdiksi atau lintas daerah/regional. Provinsi juga menjalankan fungsi lokal yang tidak dapat dijalankan oleh pemerintah kabupaten/kota karena keterbatasan sumber daya. Termasuk di dalamnya adalah fungsi perencanaan makro regional, pengembangan dan penelitian sumber daya manusia, pengelolaan pelabuhan regional, perlindungan lingkungan hidup, perdagangan dan promosi pariwisata, pengendalian/ karantina hama; dan perencanaan tata ruang.

Namun demikian, hampir semua fungsi berkenaan dengan pelayanan publik lokal ditangani oleh kabupaten/kota. Pemerintah kabupaten/kota memiliki tanggung jawab keuangan untuk sekurangkurangnya 14 (empat belas) urusan pemerintahan dan layanan lokal, seperti: pekerjaan umum lokal, layanan kesehatan dasar, layanan pendidikan primer dan sekunder dan budaya, lingkungan setempat, pertanahan, koperasi dan tenaga kerja, dan lain-lain. Tanggung jawab tersebut meliputi kegiatan, seperti perencanaan, penerapan pembiayaan, monitoring dan evaluasi, dan pemeliharaan.

Secara umum, konsep otonomi menurut UU No. 32 tahun 2004 dapat diuraikan sebagai berikut:

1. General competency untuk kabupaten/kota (kewenangan selain kewenangan Pemerintah dan provinsi).

2. Terjadi pembagian kewenangan antara pemerintah pusat, pemerintah daerah provinsi, dan pemerintah daerah kabupaten/kota.

3. Berlaku prinsip subsidiarity (concurrent), yaitu kewenangan di setiap bidang dan dapat dibagi antar tingkatan pemerintahan.

4. Kewenangan sebuah kota besar akan berbeda dengan kewenangan sebuah kota kecil. Kota besar dapat saja memiliki kewenangan pilihan yang jauh lebih banyak di banding kota kecil. Kabupaten dapat memiliki kewenangan yang berbeda dengan kota.

5. Otonomi terbatas di provinsi (kewenangan provinsi dibatasi oleh Peraturan Pemerintah Nomor 32 Tahun 2007).

6. Hubungan pemerintah daerah provinsi dengan pemerintah daerah kabupaten/kota, tidak bersifat hierarkis.

7. Provinsi diberi tugas koordinasi dan supervisi dan fungsi lintas kabupaten/kota.

\section{Desentralisasi FISKAL}

Desentralisasi diartikan sebagai pelimpahan kewenangan oleh pemerintah pusat kepada pemerintah daerah yang ada dalam wilayahnya. Istilah lain dari desentralisasi adalah otonomi, yang berarti penyelenggaraan urusan sendiri dan menolak intervensi pemerintah pusat untuk semua kewenangan yang sudah diserahkan pada daerah. Istilah otonomi berkonotasi lebih luas dari istilah desentralisasi. Desentralisasi lebih berkonotasi parsial dan otonomi lebih berkonotasi general. Pengertian otonomi ataupun desentralisasi akan lebih jelas jika dikaitkan dengan tugas apa yang mestinya diemban pemerintah baik pusat maupun daerah. Sedangkan tugas-tugas yang tidak dapat didesentralisasikan adalah politik luar negeri, pertahanan, dan moneter. Ketiga urusan ini menyangkut entitas suatu negara. Selain 
ketiga urusan tersebut, semua urusan lain pada dasarnya dapat dilimpahkan ke daerah. Derajat pelimpahan kekuasaan inilah yang menentukan tingkat otonomi daerahnya. Suatu sistem federasi murni menganut prinsip bahwa segala kekuasaan/urusan selain yang tiga di atas adalah urusan negara bagian. Namun dalam prakteknya tidak semua urusan pelayanan umum dapat ditangani oleh pemerintah negara bagian karena pemerintah federasi (pusat) keterbatasan keuangan. Sehingga penyediaan fasilitas umum yang memerlukan investasi besar misalnya jaringan transportasi negara biasanya tetap dilakukan oleh pemerintah federasi.

\section{ANGGARAN PENDAPATAN BELANJA DAERAH}

APBD merupakan wujud tahunan dari rencana jangka panjang daerah serta rencana jangka menengah yang dibuat dari visi dan misi kepala daerah. APBD dipersiapkan oleh pemerintah daerah, dibahas dan disetujui oleh Dewan Perwakilan Rakyat Daerah sehingga pada akhirnya merupakan produk hukum berupa Peraturan Daerah yang harus diikuti oleh segenap lembaga di daerah.

\section{Rancangan Penelitian}

\section{METODE PENELITIAN}

Berdasarkan jenisnya penelitian ini diklasifikasikan pada jenis penelitian survei, yang menggunakan instrumen Public Financial Management (PFM). Pada penelitian ini juga akan dilakukan wawancara mendalam mengenai optimalisasi pengelolaan keuangan dilihat dari aspek pencegahan terjadinya penyimpangan keuangan (fraud).

Tujuan menggunakan instrumen Public Financial Management (PFM) untuk mengetahui bagaimana pengelolaan keuangan daerah apakah telah optimal ditinjau dari aspek atau dimensi (i) terpenuhinya kerangka peraturan perundangan daerah; (ii) perencanaan dan penganggaran; (iii) pengelolaan kas; (iv) pengadaan barang dan jasa; (v) akuntansi dan pelaporan; (vi) pengawasan intern; (vii) hutang dan investasi publik; (viii) pengelolaan aset; serta (ix) audit dan pengawasan eksternal.

\section{Teknik Pengumpulan Data}

Teknik pengumpulan data menggunakan instrumen kuisioner/angket dan wawancara terbuka untuk mengali berbagai informasi mengenai pengelolaan keuangan. Kuisioner/angket yang digunakan adalah instrumen Public Financial Management (PFM) dengan 150 pertanyaan/pernyataan yang terbagi dalam 9 bagian, yaitu:

BIDANG $1 \quad$ : KERANGKA PERATURAN PERUNDANGAN DAERAH

BIDANG $2 \quad:$ PERENCANAAN DAN PENGANGGARAN

BIDANG 3 : PENGELOLAAN KAS

BIDANG 4 : PENGADAAN

BIDANG 5 : AKUNTANSI DAN PELAPORAN

BIDANG 6 : PENGAWASAN INTERN

BIDANG 7 : HUTANG DAN INVESTASI PUBLIK

BIDANG 8 : PENGELOLAAN ASET

BIDANG 9 : AUDIT DAN PENGAWASAN EKSTERNAL

\section{Unit Analisis}

Unit analisis pada penelitian survei ini adalah Satuan Kerja Perangkat Keuangan Daerah (SKPKD), dan beberapa bagian, biro, dan badan yang berkaitan dengan beberapa aspek kunci. Unit analisis pada penelitian ini, khususnya tahap pertama, yaitu Kota Manado, Kota Bitung, dan Kabupaten Minahasa Selatan. Kota Manado dipilih dengan pertimbangan sebagai ibu kota Provinsi Sulawesi Utara, dan kota yang mendapatkan predikat Wajar Tanpa Pengecualian (WTP) pada tahun 2014 yang sebelumnya pada tahun 2013 dengan predikat Wajar Dengan Pengecualian (WDP). Kota Bitung dipilih dengan pertimbangaan sebagai salah satu kota yang telah mendapatkan penghargaan dengan predikat Wajar Tanpa Pengecualian 4 (Empat) tahun berturut-turut (2011; 2012; 2013; dan 
2014). Kabupaten Minahasa Selatan dipilih dengan pertimbangan sebagai salah satu kabupaten yang untuk pertama kali mendapatkan predikat Wajar Dengan Pengecualian.

\section{Definisi Operasional}

\section{Kerangka Peraturan Perundangan Daerah}

Kerangka peraturan perundangan daerah adalah ketersediaan perangkat peraturan perundang-undangan secara komprehensif sesuai hukum nasional mengenai penegakan hukum dan struktur yang efektif, serta perangkat perundangan mengenai transparansi dan partisipasi masyarakat dalam pengelolaan keuangan daerah.

\section{Perencanaan dan Penganggaran}

Perencanaan dan penganggaran adalah mekanisme perencanaan dan penganggaran yang bersifat multitahun, dan bersifat partisipatif, sesuai target anggaran yang realistik, dengan sistem pemantauan dan evaluasi.

\section{Pengelolaan Kas}

Pengelolaan kas adalah pengelolaan kas secara efisien berdasarkan kebijakan, prosedur dan pengendalian yang meliputi sistem dan prosedur penerimaan kas, pembayaran kas, serta pengelolaan surplus kas temporer, sistem penagihan dan pemungutan pendapatan daerah, serta manajemen pendapatan.

\section{Pengadaan Barang dan Jasa}

Pengandaan barang dan jasa adalah kegiatan pengadaan barang dan jasa (milik daerah) secara efisien untuk menghasilkan peningkatan kompetisi dan nilai uang secara transparansi dan akuntabilitas.

\section{Akuntansi dan Pelaporan}

Akuntansi dan pelaporan adalah kapasitas SDM, kelembagaan, dan sistem informasi terintegrasi untuk seluruh transaksi dan saldo keuangan secara akurat dan tepat waktu dalam laporan keuangan dan informasi manajemen anggaran.

\section{Pengawasan Intern}

Pengawasan intern adalah berfungsinya internal audit yang efektif dan efisien mulai dari standar dan prosedur audit internal sampai tindak lanjut temuan.

\section{Hutang dan Investasi Publik}

Hutang dan investasi publik adalah kebijakan, prosedur, serta pengendalian dan pinjaman investasi daerah yang memperhitungkan resiko, dan pengelolaan penerimaan hibah telah ditetapkan dan dilaksanakan.

\section{Pengelolaan Aset}

Pengelolaan aset adalah kebijakan yang mengatur penggunaan, pemanfaatan, pemeliharaan aset daerah, serta sistem dan prosedur pencatatan, perolehan, penilaian, pemindahtangan dan penghapusan dan pelaporan barang daerah yang efektif.

\section{Audit dan Pengawasan Eksternal}

Audit dan pengawasan eksternal adalah pelaksanaan audit eksternal dan pemantauan rutin dan independen secara efektif dan akuntabilitas terhadap manajemen keuangan daerah

\section{Teknik Analisis}

Teknik Analisis yang digunakan adalah Model Analisa Keuangan Publik (Public Financial Management), dengan cara:

- Setiap indikator terdiri dari beberapa pernyataan/pertanyaan yang menunjukkan pencapaian outcome pada daerah yang dianalisis;

- $\quad$ Setiap indikator terdapat kemungkinan jawaban berdasarkan keadaan realita sebenarnya, dan bernilai antara 0 sampai 1; 
- $\quad$ Skor diakumulasikan untuk setiap hasil dan bidang strategis;

- Setiap hasil dan bidang strategis memiliki skor maksimal sesuai dengan jumlah indikator yang berada dibawahnya.

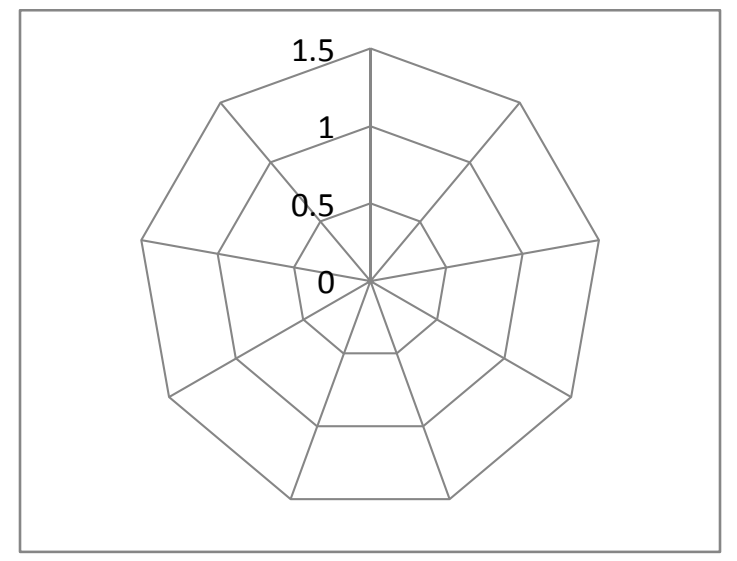

\section{Gambar 1.Model Analisis Public Financial Mangement}

Setelah hasil PFM untuk masing-masing daerah kabupaten/kota diperoleh, maka akan dianalisis aspek atau dimensi kunci yang direkomendasikan perlu untuk meningkatkan kapasitas pengelolaan keuangan.

\section{TEMUAN: ANALISIS PENGELOLAAN KEUANGAN PUBLIK}

Analisis Pengelolaan Keuangan Publik bertujuan untuk mengetahui kapasitas pengelolaan keuangan daerah. Instrumen analisis yang digunakan adalah instrumen Public Financial Management yang dikembangkan Bank Dunia. Berdasarkan rencana penelitian, tahap pertama analisis Pengelolaan Keuangan Publik dilakukan pada Kota Manado, Kota Bitung, Kabupaten Minahasa Selatan. Tahap kedua sesuai rencana dilakukan pada Kota Tomohon dan Kabupaten Minahasa Utara.

Instrumen Public Financial Management (PFM) merupakan sebuah balance scorecard system yang terdiri dari 9 kunci strategis yakni kerangka peraturan perundangan daerah, perencanaan dan penganggaran, pengelolaan kas, pengadaan barang dan jasa, akuntansi dan pelaporan, pengawasan internal, hutang dan investasi publik, pengelolaan aset, serta audit dan pengawasan eksternal. Berdasarkan Public Financial Management Instrument, setiap aspek kunci akan dilihat apakah dalam pengelolaan keuangan daerah telah optimal atau perlu perbaikan. Hasil dari pengukuran Public Financial Management Instrument dijelaskan secara berturut-turut, mulai dari Kota Manado, Kota Bitung, dan Kabupaten Minahasa Selatan.

Analisis Public Financial Management (PFM) Kota Manado. Hasil analisis public financial management Kota Manado, ditunjukkan pada Gambar berikut. 


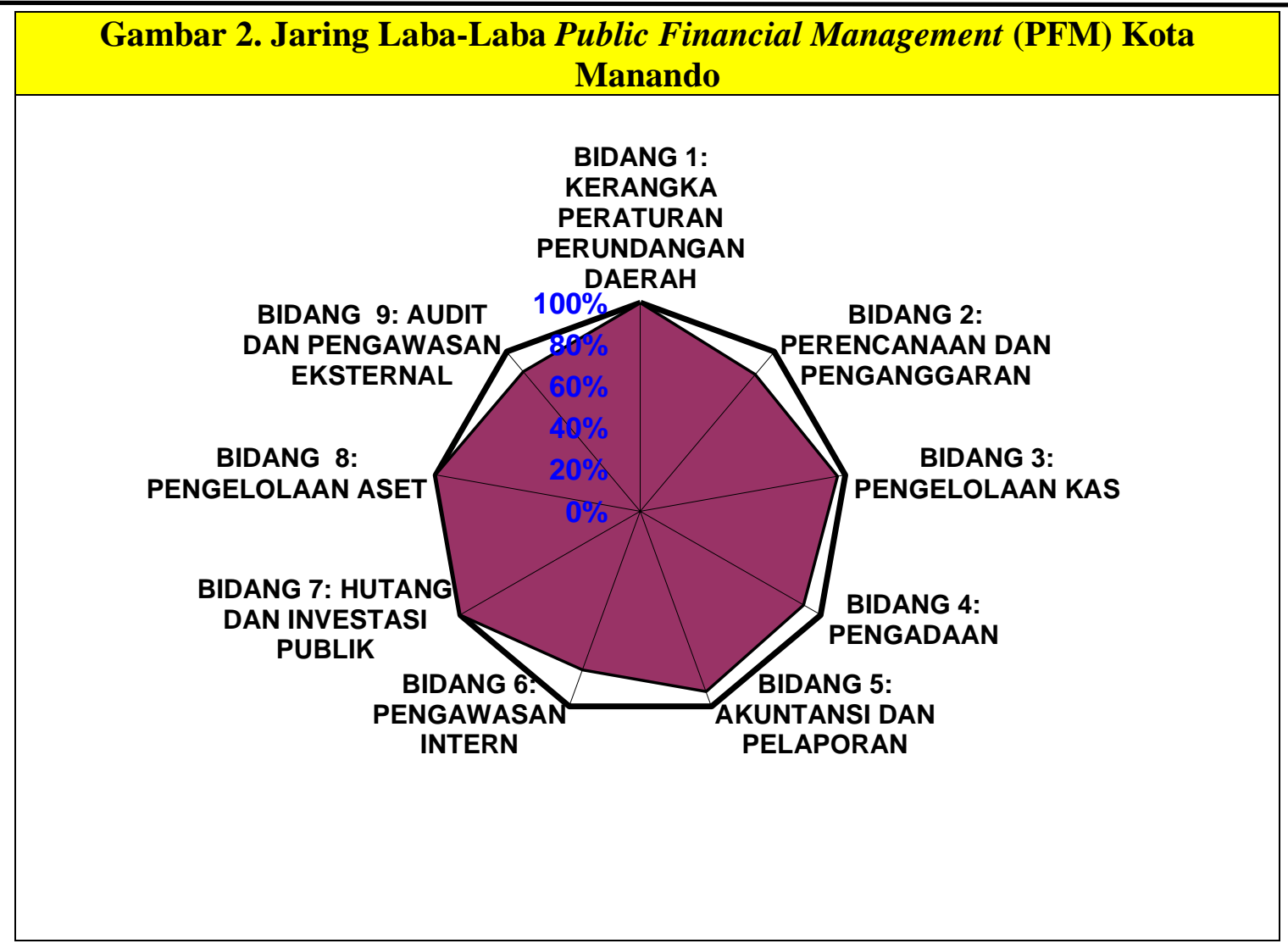

Hasil analisis public financial management Kota Manado, secara lebih jelas ditunjukkan pada Tabel berikut.

Tabel 1. Public Financial Management (PFM) Kota Manado Berdasarkan Persentase (\%) Capaian Faktor-Faktor Kunci

\begin{tabular}{lcc}
\hline \multicolumn{1}{c}{ AREA } & SCORE & $\%$ \\
\hline BIDANG 1: KERANGKA PERATURAN PERUNDANGAN DAERAH & 19 & 100 \\
\hline BIDANG 2: PERENCANAAN DAN PENGANGGARAN & 12 & 86 \\
\hline BIDANG 3: PENGELOLAAN KAS & 25 & 96 \\
\hline BIDANG 4: PENGADAAN & 19 & 90 \\
\hline BIDANG 5: AKUNTANSI DAN PELAPORAN & 12 & 92 \\
\hline BIDANG 6: PENGAWASAN INTERN & 13 & 81 \\
\hline BIDANG 7: HUTANG DAN INVESTASI PUBLIK & 9 & 100 \\
\hline BIDANG 8: PENGELOLAAN ASET & 18 & 100 \\
\hline BIDANG 9: AUDIT DAN PENGAWASAN EKSTERNAL & 7 & 88
\end{tabular}

Berdasarkan hasil analisis public financial management Kota Manado mengenai pengelolaan keuangan daerah menunjukkan bahwa dari 9 aspek yang diteliti terdapat beberapa faktor atau aspek kunci yang telah berjalan secara optimal, yaitu: tersedianya kerangka peraturan perundangan daerah, akuntansi dan pelaporan, pengelolaan hutang dan investasi publik, pengelolaan aset, serta pelaksanaan audit dan pengawasan eksternal. Sementara untuk faktor aspek kunci yang sudah baik namun perlu dioptimalkan 
lagi, seperti pengelolaan kas, pengadaan barang dan jasa, pelaksanaan audit dan pengawasan eksternal, perencanaan dan penanggaran, serta pengawasan internal.

Aspek pengelolaan kas, perlu diperhatikan dengan baik mengenai seluruh draft peraturan daerah mengenai pajak dan retribusi daerah yang diusulkan ke DEPDAGRI dan/atau DEPKEU. Ketersediaan rancangan peraturan mengenai pajak dan retribusi daerah oleh pemerintah daerah menjadi landasan penarikan pajak dan retribusi daerah. Khusus pada Kota Manado, dalam pengajuan rancangan peraturan mengenai pajak dan retribusi daerah pernah ditolak oleh DEPDAGRI dan/atau DEPKEU.

Aspek pengadaan barang dan jasa, perlu diperhatikan oleh pemerintah daerah mengenai daftar jejak rekam rekanan (daftar hitam) yang dibuat bagian pengadaan barang dan jasa agar berbagai kesalahan yang memungkinkan mengakibatkan kerugian negara dapat terhindarkan. Ketersediaan daftar jejak rekam rekanan akan memudahkan pemerintah daerah dalam menetapkan rekanan.

Aspek perencanaan dan penganggaran, perlu diperhatikan dan dihindari mengenai besaran selisih antara total anggaran belanja dengan realisasi APBD tahun lalu harus kurang dari 10\%. Rata-rata defisit realisasi anggaran selama 3 tahun terakhir tidak lebih 3\% dari PDB, serta masyarakat harus dilibatkan dalam pemantauan dan evaluasi kegiatan yang dilaksanakan di SKPD. Aspek pengawasan internal, perlu diperhatikan bahwa BAWASDA harus memiliki lebih dari 50\% staf yang mempunyai latar belakang akuntansi. Pelatihan rutin yang relevan dilakukan minimal 2 kali setahun bagi masing-masing staf BAWASDA, serta harus tersedianya sumber daya pendukung tugas operasional BAWASDA yang cukup (memadai).

Analisis Public Financial Management (PFM) Kota Bitung. Hasil analisis public financial management Kota Bitung, ditunjukkan pada Gambar berikut.

\section{Gambar 3. Jaring Laba-Laba Public Financial Management (PFM) Kota Bitung}

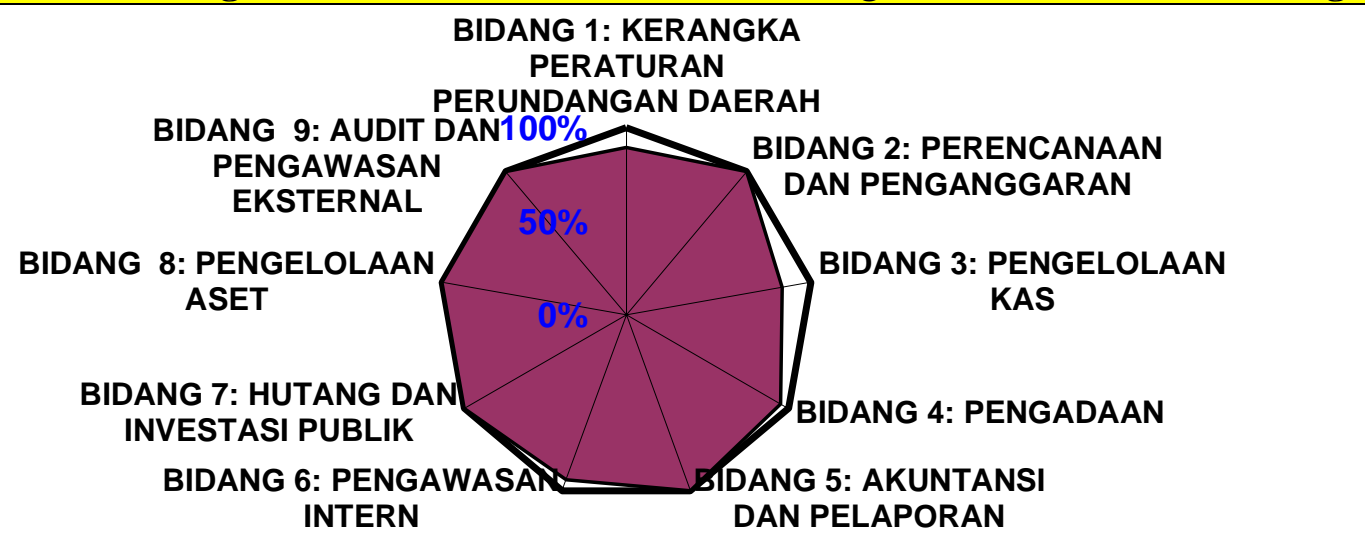

Hasil analisis public financial management Kota Manado, secara lebih jelas ditunjukkan pada Tabel berikut.

Tabel 2. Public Financial Management (PFM) Kota Bitung Berdasarkan Persentase (\%) Capaian Faktor-Faktor Kunci AREA SCORE \%

BIDANG 1: KERANGKA PERATURAN PERUNDANGAN $\quad 17 \quad 89$

DAERAH

BIDANG 2: PERENCANAAN DAN PENGANGGARAN 140

$22 \quad 85$




\begin{tabular}{lcc}
\hline BIDANG 4: PENGADAAN & 20 & 95 \\
\hline BIDANG 5: AKUNTANSI DAN PELAPORAN & 13 & 100 \\
\hline BIDANG 6: PENGAWASAN INTERN & 15 & 94 \\
\hline BIDANG 7: HUTANG DAN INVESTASI PUBLIK & 9 & 100 \\
\hline BIDANG 8: PENGELOLAAN ASET & 18 & 100 \\
\hline BIDANG 9: AUDIT DAN PENGAWASAN EKSTERNAL & 8 & 100
\end{tabular}

Berdasarkan hasil analisis public financial management Kota Bitung mengenai pengelolaan keuangan daerah menunjukkan bahwa dari 9 aspek yang diteliti terdapat beberapa faktor atau aspek kunci yang telah berjalan secara optimal, yaitu: mekanisme perencanaan dan penganggaran telah berjalan dengan baik, aspek pengadaan barang dan jasa, akuntansi dan pelaporan, pengelolaan hutang dan investasi publik, aset, dan pelaksanaan audit dan pengawasan ekternal. Sementara untuk faktor aspek kunci yang sudah baik namun perlu dioptimalkan lagi, seperti tersedianya kerangka peraturan perundangan daerah, pengelolaan kas, pengadaan barang dan jasa, serta pelaksanaan pengawasan intern.

Aspek tersedianya kerangka peraturan perundangan daerah, perlu diperhatikan bahwa peraturan perundangan daerah mengenai transparansi, dan peraturan perundangan daerah mengenai partisipasi harus disahkan. Hal ini berarti keterlibatan masyarakat dalam pengelolaan keuangan daerah perlu menjadi perhatian pemerintah daerah, dan harus diatur dalam peraturan daerah. Aspek pengelolaan kas, perlu dipertimbangkan bila terjadi surplus kas yang ada, dapat ditempatkan dalam investasi jangka pendek, serta pemberlakuan sanksi tegas bagi para penunggak utang pajak. Sementara untuk aspek pelaksanaan pengawasan intern, yaitu diperlukan kajian ulang atau revisi secara berkala untuk program dan prosedur audit secara reguler.

Analisis Public Financial Management (PFM) Kabupaten Minahasa Selatan

\begin{tabular}{|c} 
Gamabr 4. Jaring Laba-Laba Public Financial Management (PFM) \\
Kabupaten Minahasa Selatan \\
BIDANG 1: KERANGKA \\
PERATURAN \\
PERUNDANGAN DAERAH \\
BIDANG 9: AUDIT DAN \\
PENGAWASAN \\
EKSTERNAL \\
BIDANG 8: \\
BIDANG 7: HUTANG DAN \\
INVESTASI PUBLIK \\
BIDANG 6: PENGAWASAN 2: \\
INTERN
\end{tabular}


Tabel 3. Public Financial Management (PFM) Kabupaten Minahasa Selatan Berdasarkan Persentase (\%) Capaian Faktor-Faktor Kunci

\begin{tabular}{lcc}
\hline \multicolumn{1}{c}{ AREA } & SCORE & $\%$ \\
\hline BIDANG 1: KERANGKA PERATURAN PERUNDANGAN & 17 & 89 \\
DAERAH & & \\
\hline BIDANG 2: PERENCANAAN DAN PENGANGGARAN & 11,5 & 82 \\
\hline BIDANG 3: PENGELOLAAN KAS & 18 & 69 \\
\hline BIDANG 4: PENGADAAN & 18 & 86 \\
\hline BIDANG 5: AKUNTANSI DAN PELAPORAN & 10 & 77 \\
\hline BIDANG 6: PENGAWASAN INTERN & 13,5 & 84 \\
\hline BIDANG 7: HUTANG DAN INVESTASI PUBLIK & 5 & 56 \\
\hline BIDANG 8: PENGELOLAAN ASET & 11 & 61 \\
\hline BIDANG 9: AUDIT DAN PENGAWASAN EKSTERNAL & 7 & 88 \\
\hline
\end{tabular}

Berdasarkan hasil analisis public financial management Kabupaten Minahasa Selatan mengenai pengelolaan keuangan daerah menunjukkan bahwa secara keseluruhan faktor atau aspek kunci telah berjalan dengan baik, namun perlu diperbaiki, seperti: aspek kerangka peraturan perundangan daerah, perencanaan dan penganggaran, pengelolaan kas, pengadaan, akuntansi dan pelaporan, pengawasan intern, hutang dan investasi publik, pengelolaan aset, serta audit dan pengawasan eksternal.

Aspek kerangka peraturan perundangan daerah, perlu adanya peraturan perundangan daerah mengenai transparansi, dan partisipasi telah disahkan. Aspek perencanaan dan penganggaran, perlu diperhatikan bahwa dokumen perencanaan dan penganggaran harus mudah diakses oleh masyarakat. Masyarakat dilibatkan dalam pemantauan dan evaluasi kegiatan yang dilaksanakan di SKPD. Media yanga dapat digunakan pemerintah daerah, diantaranya musrenbang, website, media massa, dan sosialisasi langsung.

Aspek pengelolaan kas, perlu diperhatikan Surat Penyediaan Dana (SPD) dibuat berdasarkan Anggaran Kas, Surat Perintah Membayar (SPM) diterbitkan paling lama 2 (dua) hari setelah diterimanya SPP, dan rekonsiliasi atas rekening koran bank dengan Buku Bank dilakukan setiap bulan, surplus kas yang ada ditempatkan dalam investasi jangka pendek. Perlu peraturan kepala daerah mengenai besaran uang persediaan, dan rancangan peraturan mengenai pajak dan retribusi daerah. Rincian informasi pendukung penagihan untuk setiap pembayar pajak tersedia, dan penalti dikenakan pada pembayaran pajak dan retribusi yang terlambat. Sanksi tegas dikenakan kepada para penunggak utang pajak

Aspek pengadaan barang dan jasa, diperlukan pedoman teknis pengadaan barang dan jasa untuk disosialisasikan ke seluruh SKPD, daftar jejak rekam rekanan (daftar hitam) dibuat oleh bagian pengadaan barang dan jasa. Aspek akuntansi dan pelaporan, perlu diperhatikan bahwa masing-masing kepala bagian dalam DPPKAD adalah berlatar belakang pendidikan akuntansi atau manajemen keuangan. Paling tidak /minimal 10 persen dari staf DPPKAD merupakan lulusan D3 akuntansi atau lebih tinggi. Pejabat Penatausahaan akuntansi keuangan (PPK) SKPD berlatar belakang pendidikan akuntansi.

Aspek pengawasan intern, perlu diperhatikan bahwa BAWASDA memiliki lebih dari 50\% staf yang mempunyai latar belakang akuntansi. BAWASDA memiliki sumber daya pendukung tugas operasional yang cukup, dan temuan audit telah ditindaklanjuti oleh walikota/bupati setelah diterimanya Laporan Hasil Pemeriksaan/LHP.

Aspek hutang dan investasi publik, perlu diperhatikan total pinjaman tidak melebihi 2,5\% dari debt service coverage ratio. Terdapat peraturan mengenai penerimaan, pencatatan, pengelolaan dan pelaporan 
hibah, baik penerimaan hibah maupun pemberian hibah. Dana pendamping pelaksanaan penerimaan hibah tercantum dalam DPA SKPKD. Penerimaan hibah dicatat sebagai Pendapatan Hibah dalam kelompok Lain-lain Penerimaan yang Sah. Dilakukan publikasi informasi terhadap penerimaan dan kegiatan yang dibiayai dari Hibah

Aspek pengelolaan aset, perlu diperhatikan bahwa informasi mengenai status penggunaan barang harus ditetapkan oleh bupati/walikota. Pemanfaatan barang milik daerah dalam bentuk sewa, pinjam pakai, kerjasama pemanfaatan, atau bangun serah guna/guna serah disetujui oleh kepala daerah. Terdapat ketentuan yang mengatur tentang sanksi terhadap pengelola, pembantu pengelola, pengguna/kuasa pengguna, dan penyimpan dan/atau pengurus barang berupa Tuntutan Ganti Rugi (TGR) yang karena perbuatannya merugikan daerah. Penghapusan barang daerah dilakukan dengan alasan yang jelas dan tepat serta untuk nilai tertentu atas persetujuan bupati/walikota. Aset/barang daerah telah diberi kode lokasi dan kode barang. Setiap SKPD mempunyai kartu Inventaris barang, kartu barang inventaris dan kartu barang habis pakai. Aspek audit dan pengawasan eksternal. Aspek Masyarakat dapat menghadiri sidang DPRD yang mendiskusikan laporan pertanggungjawaban dan hasil audit BPK.

\section{Pembahasan}

\section{Aspek Kerangka Peraturan Perundang-Undangan}

Kerangka peraturan perundangan daerah adalah ketersediaan perangkat peraturan perundangundangan secara komprehensif sesuai hukum nasional mengenai penegakan hukum dan struktur yang efektif, serta perangkat perundangan mengenai transparansi dan partisipasi masyarakat dalam pengelolaan keuangan daerah. Instrumen pengukuran kerangka peraturan perundangan daerah, yaitu:

1). Adanya kerangka peraturan peraturan perundangan daerah yang komprehensif sebagaimana diamanatkan oleh kerangka hukum nasional mengenai pengelolaan keuangan daerah.

- Peraturan perundangan daerah mengenai RPJMD telah disahkan;

- Peraturan Kepala Daerah tentang Rencana Kerja Pemerintah Daerah (RKPD) telah disahkan;

- Kebijakan Umum Anggaran (KUA) dan Prioritas dan Plafon Anggaran (PPA) telah dibuat dalam suatu Nota Kesepakatan;

- Peraturan perundangan daerah mengenai APBD ditetapkan tepat waktu (sesuai dengan kalender anggaran);

- Peraturan perundangan daerah mengenai pokok-pokok pengelolaan keuangan daerah telah disahkan;

- Peraturan kepala daerah mengenai sistem dan prosedur pengelolaan keuangan daerah telah ditetapkan;

- Peraturan kepala daerah tentang kebijakan akuntansi pemerintah daerah telah ditetapkan;

- Peraturan perundangan daerah mengenai pengelolaan barang daerah telah disahkan;

- Peraturan perundangan daerah mengenai penanaman modal daerah telah disahkan;

- Peraturan perundangan daerah mengenai Badan Layanan Umum Daerah (BLUD);

- Peraturan perundang-undangan daerah tentang Standar Harga telah ditetapkan sebelum atau bersamaan dengan RKA - Rencana Kerja dan Anggaran;

- Peraturan kepala daerah tentang Standar Biaya telah ditetapkan; dan

- Peraturan kepala daerah tentang Analisis Standar Belanja telah ditetapkan

2). Kerangka peraturan perundangan daerah mengenai penegakan hukum dan struktur organisasi yang efektif.

- Peraturan perundangan daerah mengenai pengelolaan keuangan daerah disosialisasikan; 
- Diterapkannya struktur organisasi pengelola keuangan yang terpadu (berbentuk Dinas Pendapatan, Pengelola Keuangan dan Aset Daerah -DPPKAD); dan

- Peraturan Daerah mengenai SOTK (Struktur Organisasi dan Tata Kerja) Pemda sebagai tindak lanjut dari peraturan perudang-undangan yang berlaku telah disahkan.

3). Kerangka peraturan perundangan daerah mencakup ketentuan-ketentuan untuk meningkatkan transparansi dan partisipasi masyarakat.

- Peraturan perundangan daerah mengenai transparansi telah disahkan;

- Peraturan perundangan daerah mengenai partisipasi telah disahkan; dan

- Masyarakat memiliki akses terhadap sidang-sidang DPRD mengenai APBD.

Tabel 4. Capaian Aspek Kerangka Peraturan Perundangan Daerah Pada Kota Manado, Kota Bitung, dan Kabupaten Minahasa Selatan Indikator Capaian Capaian

\begin{tabular}{lccc}
\multicolumn{1}{c}{ Indikator Capaian } & \multicolumn{3}{c}{ Capaian } \\
\cline { 2 - 4 } & $\begin{array}{c}\text { Kota } \\
\text { Manado }\end{array}$ & $\begin{array}{c}\text { Kota } \\
\text { Bitung }\end{array}$ & $\begin{array}{c}\text { Kabupaten } \\
\text { MINSEL }\end{array}$ \\
\hline $\begin{array}{l}\text { Adanya Kerangka Peraturan Peraturan } \\
\text { Perundangan Daerah yang komprehensif } \\
\text { sebagaimana diamanatkan oleh kerangka } \\
\text { hukum nasional mengenai pengelolaan } \\
\text { keuangan daerah }\end{array}$ & $100,0 \%$ & $100,0 \%$ & $100,0 \%$ \\
\hline $\begin{array}{l}\text { Kerangka Peraturan Perundangan Daerah } \\
\text { Mengenai Penegakan Hukum dan Struktur } \\
\text { Organisasi yang Efektif }\end{array}$ & & & \\
\hline $\begin{array}{l}\text { Kerangka Peraturan Perundangan Daerah } \\
\text { Mencakup Ketentuan-Ketentuan untuk } \\
\text { Meningkatkan Transparansi dan Partisipasi } \\
\text { Masyarakat }\end{array}$ & $100,0 \%$ & $100,0 \%$ & $100,0 \%$ \\
\hline
\end{tabular}

Otonomi daerah dengan konsep money follows function itu sendiri, memberikan kewenangan kepada Pemerintah untuk mengatur daerahnya sendiri sebagaimana yang tercantum dalam UU No. 32 tahun 2004 tentang Pemerintahan Daerah dan dibalik kewenangan tersebut, diperlukan keuangan untuk membiayai kewenangan tersebut yang termasuk dalam UU No. 33 tahun 2004 tentang Perimbangan Keuangan antara Pemerintah Pusat dan Pemerintah Daerah. Kewenangan Pemerintah Daerah yang semakin besar ini harus diawali dengan adanya kerangka peraturan daerah tentang pengelolaan keuangan daerah, disertai dengan aspek kelembagaan yang kuat dan efektif.

Sasaran utama dilakukannya survey ini adalah melihat adanya kerangka peraturan peraturan perundangan daerah yang komprehensif sebagaimana diamanatkan oleh kerangka hukum nasional mengenai pengelolaan keuangan daerah, adanya penegakan hukum dan struktur organisasi yang efektif, dan adanya ketentuan-ketentuan yang meningkatkan transparansi dan partisipasi masyarakat.

\section{Aspek Perencanaan dan Penganggaran}

Perencanaan dan penganggaran adalah mekanisme perencanaan dan penganggaran yang bersifat multi-tahun, dan bersifat partisipatif, sesuai target anggaran yang realistik, dengan sistem pemantauan dan evaluasi. Instrumen pengukuran perencanaan dan penganggaran, yaitu:

1). Tersusunnya perencanaan dan penganggaran multi-tahun.

- Program dan kegiatan dalam RPJMD merupakan dokumen yang dapat diukur secara kuantitatif; 
- Kebijakan Umum APBD (KUA) dan PPAS (Prioritas dan Plapon Anggaran Sementara) mencakup indikator hasil yang dapat diukur;

- Dalam anggaran satuan kerja terdapat indikator-indikator hasil yang terukur dan merujuk pada strategi;

- KUA dan Prioritas dan plafon anggaran sementara (PPAS) disusun sebelum proses RKA (Rencana Kegiatan dan Anggaran) di SKPD dimulai; dan

- Telah disusun Analisis Standar Biaya

2). Target anggaran yang layak dan berdasarkan proses penyusunan anggaran yang realistis.

- Perbedaan antara total anggaran belanja dengan realisasi APBD tahun lalu kurang dari 10\%;

- Rata-rata defisit realisasi anggaran selama 3 tahun terakhir antara 0 sampai 3\% dari PDB;

- Perubahan anggaran tahun berjalan dilakukan berdasarkan alasan yang jelas sesuai dengan peraturan yang didukung oleh LRA semester I;

- Perbedaan antara APBD induk dan ABPD-P untuk kelompok belanja langsung kurang dari 10\%; dan

- Renstra dan Renja SKPD memuat Pagu indikatif (proyeksi biaya) dan mempertimbangankan keterbatasan sumber daya

3). Sistem pemantauan dan evaluasi partisipatif yang komprehensif dalam proses perencanaan dan penganggaran telah terbentuk.

- Terdapat proses evaluasi atas RKA-SKPD dalam hal kesesuaian dengan KUA dan PPAS;

- Dokumen perencanaan dan penganggaran mudah diakses oleh masyarakat;

- Masyarakat dilibatkan dalam pemantauan dan evaluasi kegiatan yang dilaksanakan di SKPD; dan

- Proses perencanaan anggaran mencakup komponen partisipatif.

Sasaran utama dalam survey ini adalah tersusunnya perencanaan dan penganggaran multi-tahun, target anggaran yang layak dan berdasarkan proses penyusunan anggaran yang realistis, adanya sistem pemantauan dan evaluasi partisipatif yang komprehensif dalam proses perencanaan dan penganggaran telah terbentuk, dan terbentuknya sistem pemantauan dan evaluasi partisipatif yang komprehensif dalam proses perencanaan dan penganggaran.

Tabel 5. Capaian Aspek Perencanaan dan Penganggaran Pada Kota Manado, Kota Bitung, dan Kabupaten Minahasa Selatan

\begin{tabular}{|c|c|c|c|}
\hline \multirow[t]{2}{*}{ Indikator Capaian } & \multicolumn{3}{|c|}{ Capaian } \\
\hline & $\begin{array}{c}\text { Kota } \\
\text { Manado }\end{array}$ & $\begin{array}{c}\text { Kota } \\
\text { Bitung }\end{array}$ & $\begin{array}{l}\text { Kabupaten } \\
\text { MINSEL }\end{array}$ \\
\hline $\begin{array}{l}\text { Tersusunnya perencanaan dan penganggaran } \\
\text { multi-tahun }\end{array}$ & $100,0 \%$ & $100,0 \%$ & $100,0 \%$ \\
\hline $\begin{array}{l}\text { Target Anggaran yang Layak dan Berdasarkan } \\
\text { Proses Penyusunan Anggaran yang Realistis }\end{array}$ & $60,0 \%$ & $100,0 \%$ & $80,0 \%$ \\
\hline $\begin{array}{l}\text { Sistem Pemantauan dan Evaluasi Partisipatif } \\
\text { yang Komprehensif dalam Proses Perencanaan } \\
\text { dan Penganggaran Telah Terbentuk }\end{array}$ & $75,0 \%$ & $100,0 \%$ & $75,0 \%$ \\
\hline
\end{tabular}

\section{Aspek Pengelolaan Kas}

Pengelolaan kas adalah pengelolaan kas secara efisien berdasarkan kebijakan, prosedur dan pengendalian yang meliputi sistem dan prosedur penerimaan kas, pembayaran kas, serta pengelolaan 
surplus kas temporer, sistem penagihan dan pemungutan pendapatan daerah, serta manajemen pendapatan. Instrumen pengukuran pengelolaan kas, yaitu:

1). Kebijakan, prosedur, dan pengendalian untuk mendorong pengelolaan kas yang efisien telah dibentuk.

- Anggaran kas dibuat berdasarkan rancangan DPA (Dokumen Pelaksanaan Anggaran);

- Surat Penyediaan Dana (SPD) dibuat berdasarkan Anggaran Kas;

- Surat Permintaan Pembayaran (SPP) dibuat berdasarkan SPD;

- Surat Perintah Membayar (SPM) diterbitkan paling lama 2 (dua) hari setelah diterimanya SPP;

- Surat Perintah Pencairan Dana (SP2D) diterbitkan paling lama 2 (dua) hari kerja setelah diterimanya pengajuan SPM;

- Ditetapkan prosedur membuka rekening bank; dan

- Pelatihan teknis fungsional kebendaharaan diikuti oleh staf bendaharawan diadakan dalam 1 (satu) tahun terakhir.

2). Penerimaan kas, pembayaran kas, serta surplus kas temporer dikelola dan dikendalikan secara efisien.

- Seluruh pendapatan asli daerah disetorkan ke dalam rekening kas umum daerah;

- Seluruh pendapatan asli daerah disetor ke rekening kas umum daerah paling lama 1 (satu) hari kerja;

- Terdapat buku rekapitulasi penerimaan harian;

- Rekonsiliasi atas rekening koran bank dengan Buku Bank dilakukan setiap bulan;

- Laporan realisasi anggaran kas dibuat setiap bulan;

- Surplus kas yang ada ditempatkan dalam investasi jangka pendek;

- Semua tempat menyimpan uang SKPD merupakan rekening atas nama pemerintah daerah; dan

- Terdapat peraturan kepala daerah mengenai besaran uang persediaan.

3). Terdapat sistem penagihan dan pemungutan pendapatan daerah yang efisien.

- Tidak ada rancangan peraturan mengenai pajak dan retribusi daerah yang ditolak oleh pemerintah (DEPDAGRI atau DEPKEU);

- Rincian informasi pendukung penagihan untuk setiap pembayar pajak tersedia;

- Dasar penetapan pajak pendapatan daerah (SKP Daerah/SKR Daerah) diverifikasi setiap tahun;

- Sistem penagihan dan pemungutan terintegrasi;

- Penalti dikenakan pada pembayaran pajak dan retribusi yang terlambat;

- Tersedia layanan untuk menanggapi pertanyaan para pembayar pajak;

- Pelatihan manajemen pendapatan daerah telah diberikan kepada staf pengelola keuangan daerah;

- Sanksi tegas telah dikenakan kepada para penunggak utang pajak; dan

- Rekonsiliasi harian dilakukan oleh bagian keuangan terhadap rekening bank yang terkait dengan pendapatan daerah.

4). Peningkatan dan penanganan manajemen pendapatan.

- Pemda telah menganalisis potensi PAD untuk perhitungan target pendapatan; dan

- Ada peningkatan realisasi penerimaan pajak dan retribusi daerah selama 3 tahun terakhir secara riil.

Pengelolaan Kas merupakan suatu rangkaian proses yang dimulai dengan perencanaan dan penganggaran besaran pendapatan dan pengeluaran kas, pelaksanaan atas penganggaran, dan pertanggungjawaban atas kas tersebut. Agar dapat melakukan pengelolaan kas yang efisien, efektif dan ekonomis; Pemerintah Daerah wajib menetapkan kebijakan dan prosedur yang jelas untuk penyelenggaraan pengelolaan kas dengan adanya Peraturan Daerah mengenai pengelolaan keuangan 
daerah, adanya Sistem dan Prosedur Penerimaan dan Pengeluaran Kas, serta adanya Kebijakan yang berkaitan dengan pengelolaan kas. Sehingga pada tahapan implementasinya, Pemerintah Daerah akan melakukannya dengan membuat anggaran Kas (berdasarkan dokumen pelaksanaan anggaran) sebagai alat kontrol yang sangat penting dengan tujuan untuk mengatur ketersediaan dana agar cukup untuk mendanai pengeluaran pemerintahan dan sesuai dengan rencana penarikan dana.

Anggaran kas terdiri dari berapa besar arus kas yang masuk dan berapa besar arus kas yang keluar setiap bulan atau triwulan dalam satu tahun anggaran. Kemudian sistem dan prosedurnya dilakukan dengan melalui tahap-tahap dalam penatausahaan keuangan daerah.

Pengelolaan kas yang telah dilakukan oleh Pemerintah Provinsi menunjukkan hasil yang paling baik diantara kabupaten dan kota. Adapun Sasaran pada bidang pengelolaan kas adalah kebijakan, prosedur, dan pengendalian untuk mendorong pengelolaan kas yang efisien telah dibentuk, penerimaan kas, pembayaran kas, serta surplus kas temporer dikelola dan dikendalikan secara efisien, terdapat sistem penagihan dan pemungutan pendapatan daerah yang efisien, dan peningkatan dan penanganan manajemen pendapatan.

Tabel 6. Capaian Aspek Pengelolaan Kas Pada Kota Manado, Kota Bitung, dan Kabupaten Minahasa Selatan

\begin{tabular}{lccc}
\hline \multicolumn{1}{c}{ Indikator Capaian } & \multicolumn{3}{c}{ Capaian } \\
\cline { 2 - 4 } & $\begin{array}{c}\text { Kota } \\
\text { Manado }\end{array}$ & $\begin{array}{c}\text { Kota } \\
\text { Bitung }\end{array}$ & $\begin{array}{c}\text { Kabupaten } \\
\text { MINSEL }\end{array}$ \\
\hline $\begin{array}{l}\text { Kebijakan, Prosedur, dan Pengendalian untuk } \\
\text { Mendorong Pengelolaan Kas yang Efisien Telah } \\
\text { Dibentuk }\end{array}$ & $\mathbf{1 0 0 , 0 \%}$ & $\mathbf{1 0 0 , 0 \%}$ & $\mathbf{7 8 , 6 \%}$ \\
\hline $\begin{array}{l}\text { Penerimaan Kas, Pembayaran Kas, Serta Surplus } \\
\text { Kas Temporer Dikelola dan Dikendalikan Secara } \\
\text { Efisien }\end{array}$ & $\mathbf{1 0 0 , 0 \%}$ & $\mathbf{8 7 , 5 \%}$ & $\mathbf{6 8 , 8 \%}$ \\
$\begin{array}{l}\text { Terdapat Sistem Penagihan dan Pemungutan } \\
\text { Pendapatan Daerah yang Efisien }\end{array}$ & $\mathbf{8 8 , 9 \%}$ & $\mathbf{8 8 , 9 \%}$ & $\mathbf{5 5 , 6 \%}$ \\
\hline $\begin{array}{l}\text { Peningkatan dan Penanganan Manajemen } \\
\text { Pendapatan }\end{array}$ & $\mathbf{1 0 0 , 0 \%}$ & $\mathbf{1 0 0 , 0} \%$ & $\mathbf{1 0 0 , 0} \%$ \\
\hline
\end{tabular}

\section{Aspek Pengadaan Barang dan Jasa}

Pengandaan barang dan jasa adalah kegiatan pengadaan barang dan jasa (milik daerah) secara efisien untuk menghasiplkan peningkatan kompetisi dan nilai uang secara transparansi dan akuntabilitas. Instrumen pengukuran pengadaan barang dan jasa, yaitu:

1). Efisiensi dalam kegiatan pengadaan barang dan jasa daerah yang menghasilkan peningkatan kompetisi, menyediakan peningkatan nilai uang (penghematan) belanja daerah, menciptakan transparansi yang lebih baik, serta menghasilkan akuntabilitas yang lebih baik.

- Pelelangan terbatas atau penunjukan langsung hanya digunakan dalam kondisi tertentu sebagaiman diatur dalam peraturan perundang-undangan yang berlaku secara optimal;

- Terdapat usulan kebutuhan barang daerah yang dibahas bersama antara pengguna barang (SKPD) dan pengelola barang (Setda) dengan memperhatikan spesifikasi barang, dan standar harga;

- Setidaknya seorang anggota panitia tender sudah memiliki sertifikat keahlian pengadaan barang dan jasa;

- Terdapat perencanaan untuk mensertifikasi staf pengadaan;

- Telah dilakukan seleksi yang ketat terhadap dokumen prakualifikasi sehingga tidak ada calon rekanan yang tidak kompeten;

- Penawaran tender diumumkan di koran atau website pengadaan nasional; 
- Harga perkiraan sendiri (HPS) disusun dengan harga yang wajar untuk setiap pengadaan barang dan jasa;

- Penjelasan lelang dilakukan dengan terbuka dan dihadiri oleh seluruh peserta yang dibuktikan dengan daftar hadir;

- Penyerahan dokumen lelang semuanya tepat waktu sesuai jadwal, tidak ada dokumen yang diterima oleh panitia setelah semua dokumen penawaran tender dibuka;

- Kriteria evaluasi jelas dan transparan;

- Calon pemenang tender diumumkan di papan pengumuman resmi dan atau internet;

- Ada catatan dan tindak lanjut atas sanggahan dari peserta tender;

- Pemenang lelang adalah yang memiliki skor paling tinggi atau penawaran paling rendah?;

- Kontrak mengatur dengan jelas uang jaminan pelaksanaan dan uang muka proyek;

- Barang/jasa yg diserahkan telah sesuai dengan spesifikasi yang ditentukan;

- Terdapat Peraturan Bupati/Walikota mengenai Pedoman Teknis Pengadaan Barang Jasa;

- Pedoman Teknis Pengadaan Barang dan Jasa telah disosialisasikan ke seluruh SKPD;

- Terdapat Unit Layanan Pengadaan yang membantu melaksanakan pengadaan barang dan jasa;

- Pejabat pengadaan dan panitia pengadaan menandatangani pakta integritas;

- Terdapat daftar jejak rekam rekanan (daftar hitam) dibuat oleh bagian pengadaan barang dan jasa; dan

- Hasil audit BPK terhadap LKPD terakhir tidak memuat temuan yang terkait dengan pengadaan barang dan jasa.

Pengadaan barang dan jasa diatur dalam Keputusan Presiden No. 80 tahun 2003 yaitu tentan pedoman pelaksanaan pengadaan barang/jasa pemerintah. Dimana pengadaan barang / jasa wajib menerapkan prinsip-prinsip efisien, efektif, terbuka dan bersaing, transparan, adil / tidak diskriminatif, dan akuntabel. Tujuan dilakukannya survey ini adalah untuk melihat peningkatkan efisiensi dalam kegiatan pengadaan barang dan jasa daerah yang menghasilkan peningkatan kompetisi, penyediaan peningkatan nilai uang (penghematan) belanja daerah, dan penciptaan transparansi yang lebih baik, serta menghasilkan akuntabilitas lebih baik.

Tabel 7. Capaian Aspek Pengadaan Barang dan Jasa Pada Kota Manado, Kota Bitung, dan Kabupaten Minahasa Selatan Indikator Capaian Capaian

\begin{tabular}{lccc}
\hline \multicolumn{1}{c}{ Indikator Capaian } & \multicolumn{3}{c}{ Capaian } \\
\cline { 2 - 4 } & $\begin{array}{c}\text { Kota } \\
\text { Manado }\end{array}$ & $\begin{array}{c}\text { Kota } \\
\text { Bitung }\end{array}$ & $\begin{array}{c}\text { Kabupaten } \\
\text { MINSEL }\end{array}$ \\
\hline $\begin{array}{l}\text { Meningkatkan efisiensi dalam kegiatan } \\
\text { pengadaan barang dan jasa daerah yang }\end{array}$ & $\mathbf{9 0 , 5 \%}$ & $\mathbf{1 0 0 , 0 \%}$ & $\mathbf{8 5 , 7 \%}$ \\
$\begin{array}{l}\text { menghasilkan peningkatan kompetisi, } \\
\text { menyediakan peningkatan nilai uang } \\
\text { (penghematan) belanja daerah, menciptakan } \\
\text { transparansi yang lebih baik, serta menghasilkan } \\
\text { akuntabilitas yang lebih baik. }\end{array}$ & & & \\
\hline
\end{tabular}

\section{Aspek Akuntansi dan Pelaporan}

Akuntansi dan pelaporan adalah kapasitas SDM, kelembagaan, dan sistem informasi terintegrasi untuk seluruh transaksi dan saldo keuangan secara akurat dan tepat waktu dalam laporan keuangan dan informasi manajemen anggaran. Instrumen pengukuran akuntansi dan pelaporan, yaitu:

1). Adanya kapasitas SDM dan kelembagaan yang memadai untuk fungsi akuntansi dan keuangan. 
- Masing-masing kepala bagian dalam DPPKAD adalah berlatar belakang pendidikan akuntansi atau manajemen keuangan;

- Paling tidak /minimal 10 persen dari staf DPPKAD merupakan lulusan D3 akuntansi atau lebih tinggi;

- Pejabat Penatausahaan akuntansi keuangan (PPK) SKPD berlatar belakang pendidikan akuntansi;

- Terdapat pejabat pengelola keuangan (PPK) di setiap SKPD;

- Dilakukan pelatihan akuntansi dan Laporan Keuangan secara rutin kepada PPK SKPD; dan

- Pernah diselenggarakan pelatihan Akuntansi dan Laporan Keuangan kepada PPK SKPD.

2). Sistem informasi akuntansi dan manajemen sudah terintegrasi.

- Laporan keuangan dan laporan kinerja dihasilkan dari satu sistem; dan

- Terdapat Buku Jurnal, Buku Besar, Buku Besar Pembantu, dan Neraca Saldo.

3). Seluruh transaksi dan saldo keuangan pemerintah daerah dicatat secara akurat dan tepat waktu.

- Telah dilaksanakan praktik akuntansi berpasangan (double entry accounting);

- Terdapat neraca awal SKPD;Terdapat rincian pos-pos laporan keuangan.

4). Terdapat laporan keuangan dan informasi manajemen anggaran yang dapat diandalkan.

- Laporan keuangan disusun dan disajikan berdasarkan standar akuntansi pemerintahan; dan

- Terdapat manual akuntansi sebagai pedoman pelaksanaan akuntansi dan penyusunan laporan keuangan.

Akuntansi dan pelaporan merupakan tantangan terbesar bagi Provinsi dan Kabupaten / Kota. Secara keseluruhan belum terdapat satu (1) daerah manapun yang memiliki nilai $>54$. Alat ukurnya dapat dilihat padanya: adanya Kapasitas SDM dan Kelembagaan yang Memadai untuk Fungsi Akuntansi dan Keuangan, Sistem Informasi Akuntansi dan Manajemen Sudah Terintegrasi, Seluruh Transaksi dan Saldo Keuangan Pemerintah Daerah Dicatat Secara Akurat dan Tepat Waktu, dan Terdapat Laporan Keuangan dan Informasi Manajemen Anggaran yang Dapat Diandalkan.

Akuntansi dan pelaporan merupakan bagian yang penting dalam pertanggungjawaban pengelolaan keuangan daerah karena itu diperlukan bukan hanya pada sistem tapi juga pada sumber daya pengelola keuangan. Dimana sistem yang ada memberikan kemudahan pada pengelola keuangan dalam melakukan kegiatan agar lebih cepat dalam melakukan pelaporan keuangan, tetapi hal itu harus didukung oleh kapasitas sumber daya manusia. 


\begin{tabular}{lccc}
\hline \multicolumn{3}{c}{$\begin{array}{c}\text { Tabel 8. Capaian Aspek Akuntansi dan Pelaporan } \\
\text { Pada Kota Manado, Kota Bitung, dan Kabupaten Minahasa Selatan }\end{array}$} \\
\cline { 2 - 4 } & \multicolumn{3}{c}{ Capaian } \\
\hline \multicolumn{1}{c}{ Indikator Capaian } & $\begin{array}{c}\text { Kota } \\
\text { Manado }\end{array}$ & $\begin{array}{c}\text { Kitung } \\
\text { Mabupaten } \\
\text { MINSEL }\end{array}$ \\
\hline $\begin{array}{l}\text { Adanya Kapasitas SDM dan Kelembagaan yang } \\
\text { Memadai untuk Fungsi Akuntansi dan Keuangan }\end{array}$ & $100,0 \%$ & $100,0 \%$ & $50,0 \%$ \\
\hline $\begin{array}{l}\text { Sistem Informasi Akuntansi dan Manajemen } \\
\text { Sudah Terintegrasi }\end{array}$ & $100,0 \%$ & $100,0 \%$ & $100,0 \%$ \\
\hline $\begin{array}{l}\text { Seluruh Transaksi dan Saldo Keuangan } \\
\text { Pemerintah Daerah Dicatat Secara Akurat dan } \\
\text { Tepat Waktu }\end{array}$ & $100,0 \%$ & $100,0 \%$ & $100,0 \%$ \\
\hline $\begin{array}{l}\text { Terdapat Laporan Keuangan dan Informasi } \\
\text { Manajemen Anggaran yang Dapat Diandalkan }\end{array}$ & $100,0 \%$ & $100,0 \%$ & $100,0 \%$ \\
\hline
\end{tabular}

\section{Aspek Pengawasan Intern}

Pengawasan intern adalah berfungsinya internal audit yang efektif dan efisien mulai dari standar dan prosedur audit internal sampai tindak lanjut temuan. Instrumen pengukuran pengawsan intern, yaitu:

1). Ditetapkan dan terpeliharanya fungsi internal audit yang efektif dan efisien;

- Peran dan tanggung jawab Bawasda ditetapkan secara jelas dalam Peraturan Daerah;

- Bawasda memiliki Program Kerja Pengawasan Tahunan (PKPT);

- Bawasda memiliki lebih dari 50\% staf berkualifikasi Jabatan Fungsional Auditor;

- Bawasda memiliki lebih dari 50\% staf yang mempunyai latar belakang akuntansi;

- Pelatihan rutin yang relevan dilakukan minimal 2 kali setahun;

- Bawasda memiliki sumber daya pendukung tugas operasional yang cukup;

- Bawasda menggunakan standar audit internal;

- Bawasda memiliki manual program dan prosedur audit internal.

2). Standar dan prosedur audit internal yang diaplikasikan dapat diterima.

- Audit internal dilaksanakan sesuai dengan Program dan Prosedur Audit yang telah dibuat;

- Bawasda mengaudit seluruh kegiatan pemerintah daerah, termasuk kegiatan komersial yang dilakukan;

- Bawasda secara reguler menguji sistem pengendalian intern yang ada dan implementasinya;

- Program dan prosedur audit secara reguler dikaji ulang dan direvisi;

- Laporan audit internal menyatakan ruang lingkup pemeriksaan sebelum memberikan pendapat/kesimpulan; dan

- Laporan audit internal dikirimkan kepada Walikota/Bupati dengan tembusan ke Bawasda Provinsi dan BPK.

3). Temuan audit internal ditindaklanjuti dengan segera.

- Laporan internal audit ditujukan kepada Kepala Daerah dan ditembuskan ke pihak-pihak yang terkait; dan

- Temuan audit telah ditindaklanjuti oleh walikota/bupati setelah diterimanya Laporan Hasil Pemeriksaan/LHP.

Internal auditor sebagai bagian dari proses pengawasan atas penyelenggaran pengelolaan keuangan daerah, memiliki peranan yang penting dalam membantu daerah untuk memaksimalkan pengelolaan keuangannya. Adapun sasaran bidang pengawasan internal adalah ditetapkan dan terpeliharanya fungsi internal audit yang efektif dan efisien, standar dan prosedur audit internal yang diaplikasikan dapat diterima, temuan audit internal ditindaklanjuti dengan segera. 
Tabel 9. Capaian Aspek Pengawasan Itern

Pada Kota Manado, Kota Bitung, dan Kabupaten Minahasa Selatan

\begin{tabular}{lccc}
\hline \multicolumn{1}{c}{ Indikator Capaian } & \multicolumn{3}{c}{ Capaian } \\
\cline { 2 - 4 } & $\begin{array}{c}\text { Kota } \\
\text { Manado }\end{array}$ & $\begin{array}{c}\text { Kota } \\
\text { Bitung }\end{array}$ & $\begin{array}{c}\text { Kabupaten } \\
\text { MINSEL }\end{array}$ \\
\hline $\begin{array}{l}\text { Ditetapkan dan terpeliharanya fungsi internal } \\
\text { audit yang efektif dan efisien }\end{array}$ & $\mathbf{6 2 , 5 \%}$ & $\mathbf{1 0 0 , 0 \%}$ & $\mathbf{8 1 , 3 \%}$ \\
\hline $\begin{array}{l}\text { Standar dan Prosedur Audit Internal yang } \\
\text { Diaplikasikan Dapat Diterima }\end{array}$ & $\mathbf{1 0 0 , 0 \%}$ & $\mathbf{8 3 , 3 \%}$ & $\mathbf{1 0 0 , 0 \%}$ \\
\hline $\begin{array}{l}\text { Temuan Audit Internal Ditindaklanjuti dengan } \\
\text { Segera }\end{array}$ & $\mathbf{1 0 0 , 0 \%}$ & $\mathbf{1 0 0 , 0 \%}$ & $\mathbf{5 0 , 0 \%}$ \\
\hline
\end{tabular}

\section{Aspek Hutang dan Investasi Publik}

Hutang dan investasi publik adalah kebijakan, prosedur, serta pengendalian dan pinjaman investasi daerah yang memperhitungkan resiko, dan pengelolaan penerimaan hibah telah ditetapkan dan dilaksanakan. Instrumen pengukuran hutang dan investasi publik, yaitu:

1). Kebijakan, prosedur, serta pengendalian dan pinjaman investasi daerah yang memperhitungkan resiko telah ditetapkan dan dilaksanakan.

- Kebijakan pengelolaan pinjaman daerah dilaksanakan sesuai dengan kerangka kebijakan nasional;

- Kebijakan pengelolaan investasi daerah dilaksanakan sesuai kerangka kebijakan nasional;

- Transaksi pinjaman dan investasi ke BUMD disajikan dalam Laporan Keuangan;

- Total pinjaman tidak melebihi $2,5 \%$ dari debt service coverage ratio; dan

- DPRD harus memberikan persetujuan atas transaksi investasi jangka panjang dengan keputusan DPRD.

2). Kebijakan, prosedur dan pengelolaan penerimaan hibah telah ditetapkan dan dilaksanakan.

- Terdapat peraturan mengenai penerimaan, pencatatan, pengelolaan dan pelaporan hibah, baik penerimaan hibah maupun pemberian hibah;

- Dana pendamping pelaksanaan penerimaan hibah tercantum dalam DPA SKPKD;

- Penerimaan hibah dicatat sebagai Pendapatan Hibah dalam kelompok Lain-lain Penerimaan yang Sah; dan

- Dilakukan publikasi informasi terhadap penerimaan dan kegiatan yang dibiayai dari Hibah.

Menurut PP No. 54 tahun 2005, Pinjaman daerah alternatif sumber pembiayaan APBD dan/atau untuk menutup kekurangan kas. Pinjaman Daerah digunakan untuk membiayai kegiatan yang merupakan inisiatif dan kewenangan Daerah berdasarkan peraturan perundang-undangan. Dalam hal Pemerintah Daerah akan melakukan pinjaman jangka menengah atau jangka panjang, Pemerintah Daerah wajib memenuhi persyaratan sebagai berikut:

a. Jumlah sisa Pinjaman Daerah ditambah jumlah pinjaman yang akan ditarik tidak melebihi $75 \%$ (tujuh puluh lima persen) dari jumlah penerimaan umum APBD tahun sebelumnya.

b. Rasio proyeksi kemampuan keuangan Daerah untuk mengembalikan pinjaman paling sedikit 2,5 (dua koma lima).

c. Tidak mempunyai tunggakan atas pengembalian pinjaman

Sasaran dalam bidang ini adalah kebijakan, prosedur, serta pengendalian dan pinjaman investasi daerah yang memperhitungkan resiko telah ditetapkan dan dilaksanakan. Secara umum, belum banyak daerah yang melakukan pinjaman kepada pihak ketiga. Akan tetapi dalam halnya dengan investasi dan 
hibah daerah, belum banyak daerah yang memiliki kebijakan dan prosedur yang menyangkut hal tersebut diatas.

Tabel 10. Capaian Aspek Hutang dan Investas Publik Pada Kota Manado, Kota Bitung, dan Kabupaten Minahasa Selatan

\begin{tabular}{lccc}
\hline \multicolumn{1}{c}{ Indikator Capaian } & \multicolumn{3}{c}{ Capaian } \\
\cline { 2 - 4 } & $\begin{array}{c}\text { Kota } \\
\text { Manado }\end{array}$ & $\begin{array}{c}\text { Kota } \\
\text { Bitung }\end{array}$ & $\begin{array}{c}\text { Kabupaten } \\
\text { MINSEL }\end{array}$ \\
\hline $\begin{array}{l}\text { Kebijakan, Prosedur, serta Pengendalian dan } \\
\text { Pinjaman Investasi Daerah yang }\end{array}$ & $\mathbf{1 0 0 , 0 \%}$ & $\mathbf{1 0 0 , 0 \%}$ & $\mathbf{8 0 , 0 \%}$ \\
$\begin{array}{l}\text { Memperhitungkan Resiko Telah Ditetapkan dan } \\
\text { Dilaksanakan }\end{array}$ & & & \\
\hline $\begin{array}{l}\text { Kebijakan, Prosedur dan Pengelolaan } \\
\text { Penerimaan Hibah telah ditetapkan dan } \\
\text { dilaksanakan }\end{array}$ & $\mathbf{1 0 0 , 0 \%}$ & $\mathbf{1 0 0 , 0 \%}$ & $\mathbf{2 5 , 0 \%}$ \\
\hline
\end{tabular}

\section{Aspek Pengelolaan Aset}

Pengelolaan aset adalah kebijakan yang mengatur penggunaan, pemanfaatan, pemeliharaan aset daerah, serta sistem dan prosedur pencatatan, perolehan, penilaian, pemindahtangan dan penghapusan dan pelaporan barang daerah yang efektif. Instrumen pengukuran pengelolaan aset, yaitu:

1). Terdapat kebijakan yang mengatur penggunaan dan pemanfaatan aset daerah yang mendukung tertib pengelolaan aset daerah.

- Terdapat informasi mengenai status penggunaan barang yang ditetapkan oleh bupati/walikota;

- Pemanfaatan barang milik daerah dalam bentuk sewa, pinjam pakai, kerjasama pemanfaatan, atau bangun serah guna/guna serah disetujui oleh kepala daerah;

- Hasil pemanfaatan barang daerah disetor ke rekening kas daerah;

- Perda Pengelolaan Barang Daerah disosialisasikan ke seluruh SKPD; dan

- Terdapat ketentuan yang mengatur tentang sanksi terhadap pengelola, pembantu pengelola, pengguna/kuasa pengguna, dan penyimpan dan/atau pengurus barang berupa Tuntutan Ganti Rugi (TGR) yang karena perbuatannya merugikan daerah.

2). Kebijakan dan prosedur pemeliharaan asset dilakukan dan terintegrasi dengan proses perencanaan daerah untuk memastikan kondisi aset selalu siap digunakan.

- Terdapat rencana tahunan kebutuhan pemeliharaan barang daerah pada setiap SKPD;

- Terdapat laporan tahunan hasil pemeliharaan barang pada di setiap SKPD; dan

- Bukti kepemilikan aset diadministrasikan dan disimpan dengan baik.

3). Terdapat kebijakan, sistem dan prosedur pencatatan, perolehan, penilaian, pemindahtangan dan penghapusan dan pelaporan barang daerah yang efektif.

- Penghapusan barang daerah dilakukan dengan alasan yang jelas dan tepat serta untuk nilai tertentu atas persetujuan bupati/walikota;

- Terdapat pencatatan barang milik daerah dalam bentuk daftar barang pengguna (DBP), sesuai penggolongan dan kodifikasi barang;

- Pengguna/pengelola barang melakukan inventarisasi barang sekurang-kurangnya sekali dalam lima tahun;

- Pengguna barang melakukan inventarisasi persediaan sekali setahun;

- Terdapat laporan barang pengguna semesteran dan tahunan;

- Terdapat laporan barang milik daerah yang disiapkan oleh pengelola barang daerah;

- Laporan barang daerah yang disiapkan oleh pengelola barang daerah merupakan sumber utama pelaporan aset dalam neraca daerah; 
- Pencatatan barang daerah telah menggunakan sistem informasi barang daerah (SIMBADA) berbasis komputer;

- Aset/barang daerah telah diberi kode lokasi dan kode barang; dan

- Setiap SKPD mempunyai kartu Inventaris barang, kartu barang inventaris dan kartu barang habis pakai

Kegiatan pengelolaan Barang Milik Daerah mencakup keseluruhan siklus pengelolaan barang yang meliputi: perencanaan kebutuhan dan penganggaran; pengadaan; penggunaan; pemanfaatan (sewa, pinjam pakai, KSP, BGS/BSG); pemeliharaan; penilaian; penghapusan; pemindahtanganan (jual, tukar menukar, hibah, PMP); penatausahaan (pembukuan, inventarisasi, pelaporan); dan pengawasan/pengendalian.

Berdasarkan hasil pemeriksaan BPK, Pemerintah Daerah sering bermasalah dalam pengelolaan aset. Pemerintah Daerah hendaknya melakukan pengelolaan aset secara efektif dan efisien. Sasaran yang hendak dicapai dalam bidang ini adalah terdapat kebijakan yang mengatur penggunaan dan pemanfaatan aset daerah yang mendukung tertib pengelolaan aset daerah, kebijakan dan prosedur pemeliharaan asset dilakukan dan terintegrasi dengan proses perencanaan daerah untuk memastikan kondisi aset selalu siap digunakan, terdapat kebijakan, sistem dan prosedur pencatatan, perolehan, penilaian, pemindahtangan dan penghapusan dan pelaporan barang daerah yang efektif.

Tabel 11. Capaian Aspek Pengelolaan Aset Pada Kota Manado, Kota Bitung, dan Kabupaten Minahasa Selatan Indikator Capaian Capaian

\begin{tabular}{lccc}
\hline \multicolumn{1}{c}{ Indikator Capaian } & \multicolumn{3}{c}{ Capaian } \\
\cline { 2 - 4 } & $\begin{array}{c}\text { Kota } \\
\text { Manado }\end{array}$ & $\begin{array}{c}\text { Kota } \\
\text { Bitung }\end{array}$ & $\begin{array}{c}\text { Kabupaten } \\
\text { MINSEL }\end{array}$ \\
\hline $\begin{array}{l}\text { Terdapat kebijakan yang mengatur penggunaan } \\
\text { dan pemanfaatan aset daerah yang mendukung } \\
\text { tertib pengelolaan aset daerah }\end{array}$ & $\mathbf{1 0 0 , 0 \%}$ & $\mathbf{1 0 0 , 0 \%}$ & $\mathbf{4 0 , 0 \%}$ \\
\hline $\begin{array}{l}\text { Kebijakan dan prosedur pemeliharaan asset } \\
\text { dilakukan dan terintegrasi dengan proses } \\
\text { perencanaan daerah untuk memastikan kondisi } \\
\text { aset selalu siap digunakan }\end{array}$ & $\mathbf{1 0 0 , 0 \%}$ & $\mathbf{1 0 0 , 0 \%}$ & $\mathbf{1 0 0 , 0 \%}$ \\
\hline $\begin{array}{l}\text { Terdapat kebijakan, sistem dan prosedur } \\
\text { pencatatan, perolehan, penilaian, } \\
\text { pemindahtangan dan penghapusan dan } \\
\text { pelaporan barang daerah yang efektif }\end{array}$ & $\mathbf{1 0 0 , 0 \%}$ & $\mathbf{1 0 0 , 0 \%}$ & $\mathbf{6 0 , 0 \%}$ \\
\hline
\end{tabular}

\section{Aspek Audit dan Pengawasan Eksternal}

Audit dan pengawasan eksternal adalah pelaksanaan audit eksternal dan pemantauan rutin dan independen secara efektif dan akuntabilitas terhadap manajemen keuangan daerah. Instrumen pengukuran audit dan pengawasan ekternal, yaitu:

1). Audit eksternal rutin menjamin efektivitas dan akuntabilitas pemerintah daerah.

- Laporan keuangan tahunan disampaikan kepada BPK paling lambat tanggal 31 Maret pada tahun anggaran berikutnya;

- Laporan Keuangan dipublikasikan misalnya melalui media massa setempat dan pada papan pengumuman resmi atau melalui web site;

- Masyarakat dapat menghadiri sidang DPRD yang mendiskusikan laporan pertanggungjawaban dan hasil audit BPK; 
- Bupati/walikota menindaklanjuti temuan audit BPK; dan

- Laporan audit eksternal minimal berstatus wajar dengan pengecualian

2). Adanya pemantau independen yang efektif terhadap manajemen keuangan daerah.

- DPRD melakukan analisa dan evaluasi terhadap laporan realisasi semester pertama dan prognosis untuk 6 (enam) bulan berikutnya;

- DPRD telah memberikan persetujuan bersama terhadap rancangan peraturan daerah tentang pertanggungjawaban pelaksanaan APBD; dan

- DPRD mengadakan rapat koordinasi dengan setiap SKPD dalam rangka pengawasan pelaksanaan APBD.

Pemeriksaan adalah proses identifikasi masalah, analisis, dan evaluasi yang dilakukan secara independen, obyektif, dan profesional berdasarkan standar pemeriksaan, untuk menilai kebenaran, kecermatan, kredibilitas, dan keandalan informasi mengenai pengelolaan dan tanggung jawab keuangan negara. BPK dalam hal ini melakukan penilaian atas laporan keuangan untuk memberikan pendapat atas laporan keuangan yang ada. Penilaian yang dilakukan ini untuk meningkatkan akuntabilitas atas laporan keuangan yang dibuat oleh Pemerintah Daerah dalam rangka good governance. Sasaran dari audit dan pengawasan eksternal ini adaalah untuk Menjamin Efektivitas dan Akuntabilitas Pemerintah Daerah, dan Adanya pemantau independen yang efektif terhadap manajemen keuangan daerah.

Tabel 12.Capaian Aspek Audit dan Pengawasan Ekternal Pada Kota Manado, Kota Bitung, dan Kabupaten Minahasa Selatan Indikator Capaian Capaian

\begin{tabular}{lccc}
\multicolumn{1}{c}{ Capaian } \\
\cline { 2 - 4 } & $\begin{array}{c}\text { Kota } \\
\text { Manado }\end{array}$ & $\begin{array}{c}\text { Kota } \\
\text { Bitung }\end{array}$ & $\begin{array}{c}\text { Kabupaten } \\
\text { MINSEL }\end{array}$ \\
\hline $\begin{array}{l}\text { Audit Eksternal Rutin Menjamin Efektivitas } \\
\text { dan Akuntabilitas Pemerintah Daerah }\end{array}$ & $\mathbf{1 0 0 , 0 \%}$ & $\mathbf{1 0 0 , 0 \%}$ & $\mathbf{8 0 , 0 \%}$ \\
\hline $\begin{array}{l}\text { Adanya pemantau independen yang efektif } \\
\text { terhadap manajemen keuangan daerah }\end{array}$ & $\mathbf{6 6 , 7 \%}$ & $\mathbf{1 0 0 , 0 \%}$ & $\mathbf{1 0 0 , 0 \%}$ \\
\hline
\end{tabular}

\section{KESIMPULAN DAN SARAN}

\section{PENUTUP}

Kota Manado berdasarkan hasil analisis public financial management Kota Manado mengenai pengelolaan keuangan daerah menunjukkan bahwa dari 9 aspek yang diteliti terdapat beberapa faktor atau aspek kunci yang telah berjalan secara optimal, yaitu: tersedianya kerangka peraturan perundangan daerah, akuntansi dan pelaporan, pengelolaan hutang dan investasi publik, pengelolaan aset, serta pelaksanaan audit dan pengawasan eksternal. Sementara untuk faktor aspek kunci yang sudah baik namun perlu dioptimalkan lagi, seperti pengelolaan kas, pengadaan barang dan jasa, pelaksanaan audit dan pengawasan eksternal, perencanaan dan penanggaran, serta pengawasan internal. Aspek pengelolaan kas, perlu diperhatikan dengan baik mengenai seluruh draft peraturan daerah mengenai pajak dan retribusi daerah yang diusulkan ke DEPDAGRI dan/atau DEPKEU. Ketersediaan rancangan peraturan mengenai pajak dan retribusi daerah oleh pemerintah daerah menjadi landasan penarikan pajak dan retribusi daerah. Khusus pada Kota Manado, dalam pengajuan rancangan peraturan mengenai pajak dan retribusi daerah pernah ditolak oleh DEPDAGRI dan/atau DEPKEU. Aspek pengadaan barang dan jasa, perlu diperhatikan oleh pemerintah daerah mengenai daftar jejak rekam rekanan (daftar hitam) yang dibuat bagian pengadaan barang dan jasa agar berbagai kesalahan yang memungkinkan mengakibatkan kerugian negara dapat terhindarkan. Ketersediaan daftar jejak rekam rekanan akan memudahkan pemerintah daerah dalam menetapkan rekanan. Aspek perencanaan dan penganggaran, perlu diperhatikan dan dihindari 
mengenai besaran selisih antara total anggaran belanja dengan realisasi APBD tahun lalu harus kurang dari 10\%. Rata-rata defisit realisasi anggaran selama 3 tahun terakhir tidak lebih 3\% dari PDB, serta masyarakat harus dilibatkan dalam pemantauan dan evaluasi kegiatan yang dilaksanakan di SKPD. Aspek pengawasan internal, perlu diperhatikan bahwa BAWASDA harus memiliki lebih dari 50\% staf yang mempunyai latar belakang akuntansi. Pelatihan rutin yang relevan dilakukan minimal 2 kali setahun bagi masing-masing staf BAWASDA, serta harus tersedianya sumber daya pendukung tugas operasional BAWASDA yang cukup (memadai).

Kota Bitung berdasarkan hasil analisis public financial management Kota Bitung mengenai pengelolaan keuangan daerah menunjukkan bahwa dari 9 aspek yang diteliti terdapat beberapa faktor atau aspek kunci yang telah berjalan secara optimal, yaitu: mekanisme perencanaan dan penganggaran telah berjalan dengan baik, aspek pengadaan barang dan jasa, akuntansi dan pelaporan, pengelolaan hutang dan investasi publik, aset, dan pelaksanaan audit dan pengawasan ekternal. Sementara untuk faktor aspek kunci yang sudah baik namun perlu dioptimalkan lagi, seperti tersedianya kerangka peraturan perundangan daerah, pengelolaan kas, pengadaan barang dan jasa, serta pelaksanaan pengawasan intern. Aspek tersedianya kerangka peraturan perundangan daerah, perlu diperhatikan bahwa peraturan perundangan daerah mengenai transparansi, dan peraturan perundangan daerah mengenai partisipasi harus disahkan. Hal ini berarti keterlibatan masyarakat dalam pengelolaan keuangan daerah perlu menjadi perhatian pemerintah daerah, dan harus diatur dalam peraturan daerah. Aspek pengelolaan kas, perlu dipertimbangkan bila terjadi surplus kas yang ada, dapat ditempatkan dalam investasi jangka pendek, serta pemberlakuan sanksi tegas bagi para penunggak utang pajak. Sementara untuk aspek pelaksanaan pengawasan intern, yaitu diperlukan kajian ulang atau revisi secara berkala untuk program dan prosedur audit secara reguler.

Kabupaten Minahasa Selatan berdasarkan hasil analisis public financial management Kabupaten Minahasa Selatan mengenai pengelolaan keuangan daerah menunjukkan bahwa secara keseluruhan faktor atau aspek kunci telah berjalan dengan baik, namun perlu diperbaiki, seperti: aspek kerangka peraturan perundangan daerah, perencanaan dan penganggaran, pengelolaan kas, pengadaan, akuntansi dan pelaporan, pengawasan intern, hutang dan investasi publik, pengelolaan aset, serta audit dan pengawasan eksternal. Aspek kerangka peraturan perundangan daerah, perlu adanya peraturan perundangan daerah mengenai transparansi, dan partisipasi telah disahkan. Aspek perencanaan dan penganggaran, perlu diperhatikan bahwa dokumen perencanaan dan penganggaran harus mudah diakses oleh masyarakat. Masyarakat dilibatkan dalam pemantauan dan evaluasi kegiatan yang dilaksanakan di SKPD. Media yanga dapat digunakan pemerintah daerah, diantaranya musrenbang, website, media massa, dan sosialisasi langsung.

Aspek pengelolaan kas, perlu diperhatikan Surat Penyediaan Dana (SPD) dibuat berdasarkan Anggaran Kas, Surat Perintah Membayar (SPM) diterbitkan paling lama 2 (dua) hari setelah diterimanya SPP, dan rekonsiliasi atas rekening koran bank dengan Buku Bank dilakukan setiap bulan, surplus kas yang ada ditempatkan dalam investasi jangka pendek. Perlu peraturan kepala daerah mengenai besaran uang persediaan, dan rancangan peraturan mengenai pajak dan retribusi daerah. Rincian informasi pendukung penagihan untuk setiap pembayar pajak tersedia, dan penalti dikenakan pada pembayaran pajak dan retribusi yang terlambat, dan sanksi tegas seharusnya dikenakan kepada para penunggak utang pajak. Aspek pengadaan barang dan jasa, diperlukan pedoman teknis pengadaan barang dan jasa untuk disosialisasikan ke seluruh SKPD, daftar jejak rekam rekanan (daftar hitam) dibuat oleh bagian pengadaan barang dan jasa. Aspek akuntansi dan pelaporan, perlu diperhatikan bahwa masing-masing kepala bagian dalam DPPKAD adalah berlatar belakang pendidikan akuntansi atau manajemen keuangan. Paling tidak /minimal 10 persen dari staf DPPKAD merupakan lulusan D3 akuntansi atau lebih tinggi. Pejabat Penatausahaan akuntansi keuangan (PPK) SKPD berlatar belakang pendidikan akuntansi. Aspek pengawasan intern, perlu diperhatikan bahwa BAWASDA memiliki lebih dari $50 \%$ staf yang mempunyai 
latar belakang akuntansi. BAWASDA memiliki sumber daya pendukung tugas operasional yang cukup, dan temuan audit telah ditindaklanjuti oleh walikota/bupati setelah diterimanya Laporan Hasil Pemeriksaan/LHP. Aspek hutang dan investasi publik, perlu diperhatikan total pinjaman tidak melebihi $2,5 \%$ dari debt service coverage ratio. Terdapat peraturan mengenai penerimaan, pencatatan, pengelolaan dan pelaporan hibah, baik penerimaan hibah maupun pemberian hibah. Dana pendamping pelaksanaan penerimaan hibah tercantum dalam DPA SKPKD. Penerimaan hibah dicatat sebagai Pendapatan Hibah dalam kelompok Lain-lain Penerimaan yang Sah. Dilakukan publikasi informasi terhadap penerimaan dan kegiatan yang dibiayai dari Hibah. Aspek pengelolaan aset, perlu diperhatikan bahwa informasi mengenai status penggunaan barang harus ditetapkan oleh bupati/walikota. Pemanfaatan barang milik daerah dalam bentuk sewa, pinjam pakai, kerjasama pemanfaatan, atau bangun serah guna/guna serah disetujui oleh kepala daerah. Terdapat ketentuan yang mengatur tentang sanksi terhadap pengelola, pembantu pengelola, pengguna/kuasa pengguna, dan penyimpan dan/atau pengurus barang berupa Tuntutan Ganti Rugi (TGR) yang karena perbuatannya merugikan daerah. Penghapusan barang daerah dilakukan dengan alasan yang jelas dan tepat serta untuk nilai tertentu atas persetujuan bupati/walikota. Aset/barang daerah telah diberi kode lokasi dan kode barang. Setiap SKPD mempunyai kartu Inventaris barang, kartu barang inventaris dan kartu barang habis pakai. Aspek audit dan pengawasan eksternal. Aspek Masyarakat dapat menghadiri sidang DPRD yang mendiskusikan laporan pertanggungjawaban dan hasil audit BPK.

\section{DAFTAR PUSTAKA}

Abdul Halim. (2001). Bunga Rampai Manajemen Keuangan Daerah, Edisi Pertama, UPP AMP YKPN, Yogyakarta.

Brodjonegoro, Bambang, and Shinji, Asanuma. (2000). "Regional Autonomy and Fiscal Decentralization in Democratic Indonesia”, Hitotsubashi Journal of Economics, Vol. 41, No. 2, 111-122.

Davey, K. J. (1988). Pembiayaan Pemerintah Daerah, Terjemahan oleh Amanullah, Hamdani Amin, A. T. Pakpahan, Busrori, Bachrul Elmi; pendamping Suntoro Isman, UI-Press, Jakarta.

Devas, Nick. (1989). Keuangan Pemerintah Daerah di Indonesia. Penerbit UI Press Jakarta.

Departemen Keuangan RI. Proceeding Workshop Nasional Penguatan Pelaksanaan Kebijakan Desentralisasi Fiskal. (2006).

Downing,B.Paul. (1992). The Revenue Potential of User Charges in Municipal Finance. Jurnal Public Finance Quartely, Volume 20,Nomor 4, 512 - 527.

Insunkindro et al. (1994). Peranan dan Pengelolaan Keuangan Daerah Dalam Usaha Peningkatan Pendapatan Asli Daerah, Fakultas Ekonomi UGM, Yogyakarta.

Kuncoro, Mudrajad. (2004). Otonomi dan Pembangunan Daerah, Reformasi, Perencanaan, Strategi dan Peluang. Penerbit Erlangga Jakarta.

Masykur Wiratmo. Manajemen Penerimaan dan Pengeluaran Daerah. Paper pada Workshop Manajemen

Strategik dan Keuangan Daerah Dalam Era otonomi Daerah. Padang 23 - 24 Juli 2001.

Musgrave, RA and Musgrave, P.B. (1984). Public Finance in Theory And

Practice. MC Graw-Hill Book Company. Singapore.

Undang-Undang No. 34 Tahun 2000., Tentang Pajak dan Retribusi Daerah.

Undang-Undang No. 33 Tahun 2004., Tentang Perimbangan Keuangan Pusat dan Daerah.

Undang-Undang No.25 Tahun 2004 tentang Sistem Perencanaan Pembangunan Nasional (SPPN).

Undang-Undang No.17 Tahun 2003 tentang Keuangan Negara.

UU No. 1/2004 Perbendaharaan Negara.

UU No.15/2004 Pemeriksaan Pengelolaan dan Tanggungjawab Keuangan Negara.

UU No. 25/2004 Sistem Perencanaan Pembangunan Nasional.

PP No. 20/2004 Penyusunan Rencana Kerja Pemerintah.

PP No. 21/2004 Penyusunan RKA-KL. 
PP No. 24/2005 Standar Akuntansi Pemerintahan.

PP No. 56/2005 Sistem Informasi Keuangan Daerah.

PP No. 58/2005 Pengelolaan Keuangan Daerah.

PP No. 65/2005 Pedoman Penyus. \& Penerapan SPM.

PP No. 8/2006 Lap Keu \& Kinerja Instansi Pemerintah. 